DOI: https://doi.org/10.47405/mjssh.v6i9.1006

\begin{tabular}{|c|c|}
\hline & Malaysian Journal of Social Sciences and Humanities (MJSSH) \\
\hline Malaysian Journal of & Volume 6, Issue 9, September 2021 \\
\hline 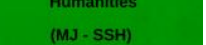 & e-ISSN : 2504-8562 \\
\hline & $\begin{array}{l}\text { Journal home page: } \\
\text { www.msocialsciences.com }\end{array}$ \\
\hline
\end{tabular}

\title{
Hubungan Antara Pembelajaran Regulasi Kendiri dan Motivasi Terhadap Pencapaian Akademik
}

\author{
Nuraisyah Muhammad1, Faridah Mydin Kutty ${ }^{1}$ \\ ${ }^{1}$ Fakulti Pendidikan, Universiti Kebangsaan Malaysia (UKM) \\ Correspondence: Nuraisyah Muhammad (p103763@siswa.ukm.edu.my)
}

\begin{abstract}
Abstrak
Keupayaan pelajar untuk kekal berdisiplin dan bermotivasi dalam pembelajaran norma baharu amatlah penting dalam melancarkan proses pembelajaran. Sehubungan itu, pembelajaran regulasi kendiri dan motivasi adalah dua elemen penting yang perlu diberi perhatian supaya dapat mengoptimumkan pencapaian akademik pelajar. Justeru kajian ini bertujuan untuk mengenal pasti hubungan antara pembelajaran regulasi kendiri dan motivasi terhadap pencapaian akademik pelajar sarjana Fakulti Pendidikan, Universiti Kebangsaan Malaysia (UKM). Kajian ini menggunakan pendekatan kuantitatif berasaskan reka bentuk tinjauan. Kaedah persampelan rawak mudah digunakan dan seramai 240 orang pelajar sarjana dari Fakulti Pendidikan, UKM telah dipilih sebagai sampel kajian. Instrumen kajian mengadaptasi soal selidik daripada Motivated Strategies for Learning Questionnaire (MSLQ). Purata Nilai Gred Kumulatif (PNGK) digunakan untuk mengukur tahap pencapaian akademik pelajar. Dapatan kajian menunjukkan pelajar mempunyai tahap motivasi dan pembelajaran regulasi kendiri yang tinggi iaitu motivasi $(\min =5.84, \mathrm{SP}=0.645)$ dan regulasi kendiri $(\min =5.36, \mathrm{SP}=0.639)$. Hasil kajian turut menunjukkan terdapat hubungan signifikan yang sederhana antara motivasi dan pencapaian akademik iaitu $(\mathrm{r}=0.405, \mathrm{p}<0.01)$ dan pembelajaran regulasi kendiri terhadap pencapaian akademik $(\mathrm{r}=0.462, \mathrm{p}<0.01)$. Kajian ini menunjukkan bahawa pembelajaran regulasi kendiri dan motivasi pelajar pada tahap yang baik. Oleh yang demikian, kajian ini dapat dijadikan sumber rujukan khususnya terhadap institusi pendidikan dan pensyarah bagi memastikan sistem pembelajaran atas talian dapat dilaksanakan dengan efisien sebagai langkah untuk mengekalkan dan memantapkan motivasi, regulasi kendiri dan pencapaian akademik pelajar.
\end{abstract}

Kata kunci: motivasi, regulasi kendiri, pencapaian akademik, pembelajaran atas talian

\section{The Relationship Between Self- Regulation and Motivation Towards Academic Achievement}

\begin{abstract}
The ability of students to remain disciplined and motivated in new norms learning is important in launching the learning process. In this regard, self-regulation learning and motivation are two important elements that need to be addressed to optimize student academic achievement. Hence, this study aims to identify the relationship between self-regulation learning and motivational learning towards academic achievement among postgraduate students of Education Faculty, Universiti Kebangsaan Malaysia (UKM). This study presents a quantitative approach based on survey design. The random sampling method is easy to use and a total of 240 postgraduate students from the Faculty of Education, UKM has been selected as a sample of the study. The research instrument adapted the
\end{abstract}


questionnaire from Motivated Strategies for Learning Questionnaire (MSLQ). The average cumulative grade value (CGPA) is used to measure the level of student academic achievement. The findings show that students have high levels of self-motivation and self-regulation learning (mean $=5.84, \mathrm{sp}=0.645$ ) and self-regulation $(\min =5.36, \mathrm{sp}=0.639)$. The findings also showed that there was a modest significant relationship between the motivation and academic achievement $(r=0.405, p<0.01)$ and self-regulatory learning to academic achievement $(r=0.462, \mathrm{p}<0.01)$. This study shows that selfregulation learning and student motivation at a good level. As such, this study can be used as a source of reference especially on educational institutions and lecturers to ensure that online learning systems can be efficiently implemented as a measure to maintain and strengthen motivation, self-regulation and academic achievement of students.

Keywords: motivation, self-regulated learning, academic achievement, online learning

\section{Pengenalan}

Kemunculan pandemik Covid-19 telah membawa perubahan baharu dalam pelbagai aspek terutamanya dalam proses pembelajaran di Malaysia. Pelajar perlu beradaptasi dengan norma baharu iaitu proses pembelajaran dilakukan secara atas talian. Dalam kajian Bolatov et al. (2021) juga menyatakan peralihan kepada pembelajaran atas talian telah mempengaruhi pencapaian akademik dan kesihatan mental pelajar. Pencapaian akademik telah terbukti wujud dalam kalangan pelajar universiti semasa mengikuti pembelajaran di atas talian (Benjamin et al., 2021; Oducado \& Eztoque, 2021; Bolatocv et al., 2021). Kebiasaannya pelajar menjangkakan dengan peningkatan usaha dan aktiviti akan menghasilkan pencapaian akademik lebih baik (Cerezo et al., 2016; Conjin et al., 2017; Motz et al., 2019). Namun, kajian Benjamin et al. (2021) terhadap pembelajaran atas talian menyatakan yang sebaliknya, pelajar menyatakan mereka kurang berjaya dan memperoleh pencapaian akademik yang lebih rendah.

Pembelajaran regulasi kendiri adalah salah satu strategi alternatif yang menyumbang kepada pencapaian akademik yang baik (Nani et al., 2021). Pembelajaran regulasi kendiri merujuk kepada keupayaan pelajar untuk memahami, mengawal dan membuat penyesuaian proses pembelajaran sebagai tindak balas mengenai status pembelajaran (Harris et al., 2011; Schunk \& Zimmerman, 1998). Menurut Nani et al. (2021), pelajar yang mempunyai pembelajaran regulasi kendiri yang baik dapat mengoptimumkan pembelajaran atas talian dan mereka menjadi lebih progresif dari segi pencapaian akademik. Selain itu, regulasi kendiri juga dilihat penting untuk dikaji kerana kebanyakan kajian sebelum ini mengkaji sampel yang memfokuskan kepada pelajar sekolah berbanding pelajar di IPT (Feng et al., 2020; Hafizhoh et al., 2020; Nor Syaheerah \& Tajul Ariffin, 2021). Hal ini adalah kerana kajian yang bersampelkan murid sekolah menunjukkan kebergantungan mereka kepada bantuan dari ibu bapa dan guru untuk mengaplikasikan kemahiran regulasi kendiri (Annie et al., 2021). Berbeza dengan pelajar IPT, di mana kemahiran regulasi kendiri mereka memerlukan kemahiran sendiri. Penyataan ini turut diperakui oleh Izzat et al. (2020) iaitu pelaksanaan pembelajaran atas talian memerlukan pelajar membina sendiri kemahiran pembelajaran mereka.

Selain itu, motivasi juga dilihat mempunyai kemampuan dalam memberi impak kepada proses pembelajaran dan pencapaian akademik (Rasha, 2020). Deci dan Ryan (1996), mendefinisikan motivasi sebagai kesediaan untuk berusaha dalam mengejar sesuatu matlamat. Menurut Kamaruzaman et al. (2010), motivasi memainkan peranan penting dalam mempengaruhi pertumbuhan, perkembangan dan pencapaian pelajar. Oleh itu terdapat keperluan untuk mengkaji sejauh mana motivasi dapat mempengaruhi pencapaian akademik sepanjang pembelajaran atas talian. Hal ini adalah kerana kebanyakan kajian lepas hanya mengkaji dalam konteks bersemuka (Haafiz, 2018; Feng et al., 2020; Rasha, 2020). Kajian Mahathir dan Wardatul (2021), mendapati pembelajaran di atas talian memberi cabaran kepada pelajar, antaranya pelajar berhadapan dengan suasana yang tidak kondusif untuk belajar dan tahap keberkesanan pembelajaran rendah. Dalam kajian Mohamed Nazul (2020) juga telah menyatakan pelajar berhadapan dengan cabaran sewaktu menjalani pembelajaran atas talian iaitu keupayaan untuk mengadaptasi perubahan teknologi. 
Sehubungan dengan itu, kajian ini adalah bertujuan untuk mengenal pasti hubungan antara pembelajaran regulasi kendiri dan motivasi terhadap pencapaian akademik pelajar sarjana sewaktu pembelajaran atas talian. Penulisan ini secara keseluruhannya terbahagi kepada beberapa subtopik iaitu bahagian pengenalan seperti yang telah dibincangkan di atas. Seterusnya ialah sorotan literatur berkaitan pembelajaran regulasi kendiri, motivasi, pencapaian akademik, teori kognitif sosial dan teori determinasi diri. Seterusnya ialah penerangan mengenai metodologi yang digunakan dalam kajian ini beserta dapatan kajian dan akhir sekali adalah perbincangan dapatan kajian.

\section{Sorotan Literatur}

\section{Pembelajaran Dalam Talian}

Pandemik Covid-19 telah memberi kesan yang besar terhadap sektor pendidikan dan sekali gus mendorong ke arah sesi pembelajaran dalam talian. Menurut Mukhtar et al. (2020), pembelajaran dalam talian melibatkan pelaksanaan kemajuan dalam teknologi untuk mengarahkan, merancang dan menyampaikan kandungan pembelajaran. Peralihan kepada pembelajaran atas talian telah menyebabkan pencapaian akademik merosot (Bolatov et al., 2021). Hal ini adalah kerana pembelajaran dalam talian semasa pandemik Covid-19 memberikan cabaran yang besar kepada pelajar (Nazrul, 2020). Antaranya ialah pelajar terbeban dengan tekanan akademik, persekitaran pembelajaran yang tidak memberangsangkan dan gangguan capaian internet (Arif \& Saodah, 2019). Menurut Aragon dan Johnson (2008), pembelajaran dalam talian turut menyebabkan pelajar kurang bermotivasi dan secara tidak langsung menghalang pertumbuhan pembelajaran dalam talian serta meningkatkan skala keciciran dalam pembelajaran (Aragon \& Johnson, 2008). Selain itu, kajian lepas turut menunjukkan pembelajaran dalam talian menyebabkan kandungan kursus sukar disampaikan dan memberi kesukaran kepada pelajar untuk memahami kandungan kursus (Rashid et al, 2020). Tambahan lain, pembelajaran dalam talian juga memerlukan komitmen dan disiplin pelajar (Mahiswaran et al., 2020). Justeru itu, pembelajaran regulasi yang baik di perlukan oleh pelajar supaya mereka dapat menentukan keutamaan, mendisiplinkan diri serta berkemahiran dalam menguruskan ilmu pengetahuan (Pintrich, 2000). Oleh itu, pembelajaran atas talian semasa Covid-19, perlu dinilai keberkesanannya terhadap sesi pembelajaran (Mukhtar et al., 2020). Kajian ini akan melihat keberkesanan pembelajaran atas talian menerusi tahap pencapaian akademik, pembelajaran regulasi kendiri dan motivasi pelajar.

\section{Pencapaian Akademik}

Menurut Santrock (2006) pencapaian merujuk kepada kemahiran atau ilmu yang telah pelajari oleh pelajar dan biasanya diukur melalui penilaian seperti ujian standard, penilaian prestasi dan penilaian portfolio. Pencapaian akademik merupakan hal yang berkait rapat dengan aktiviti pembelajaran, kerana ia merupakan proses, manakala pencapaian akademik merupakan hasilnya. Menurut pandangan kognitif sosial, pencapaian akademik dipandang sebagai hubungan yang rumit antara kemampuan individu, persepsi diri, penilaian terhadap tugas, strategi kognitif, regulasi diri, status sosio-ekonomi dan tingkah laku individu terhadap institusi (Clemons, 2008). Pencapaian akademik akan terjejas secara negatif oleh penglibatan akademik yang rendah, motivasi yang terhad, dan kelakuan tingkah laku yang pasif (Carter et al., 2011). Pencapaian akademik dilihat penting untuk mengukur aras pengetahuan pelajar, ia merupakan penentu pemahaman pelajar terhadap proses pembelajaran dan secara tidak langsung, pencapaian yang cemerlang akan menentukan masa depan yang lebih baik (Rashidi, 2011).

Di Malaysia, konsep pencapaian akademik pelajar merujuk kepada hasil penilaian tenaga pengajar terhadap satu ataupun beberapa perkara yang diajar kepada pelajar dengan memberikan markah, peratus atau gred (Abdillah \& Haleefa, 2011). Dalam kajian ini, pencapaian akademik merujuk kepada keputusan yang diperoleh oleh pelajar dalam peperiksaan yang diambil mereka. Kajian ini akan menggunakan Purata Nilai Gred Kumulatif (PNGK) kerana ia dapat memberikan maklumat prestasi akademik pelajar sepanjang masa. Kajian terhadap pencapaian akademik adalah sangat penting untuk 
membantu pengajar mengenal pasti keadaan di mana pelajar membangun dan berkembang (Ikmal Rezal Othman, 2020).

Dalam konteks pelajar di universiti, kajian berkenaan pencapaian akademik kebanyakan menyentuh aspek jantina, kursus, pengaruh kemahiran pengajar dan efikasi kendiri (Ahmad \& Nelson, 2017; Zulyna \& Faridah, 2021; Noraida \& Siti, 2021). Walau bagaimanapun, kajian terkini berkenaan pencapaian akademik terhadap pelajar universiti di Malaysia sepanjang pembelajaran atas talian masih belum diterokai sepenuhnya. Pelajar kini sedang menghadapi perubahan yang mendadak dalam proses pembelajaran, aspek pencapaian akademik penting untuk dinilai kerana aspek ini merupakan salah satu petunjuk dalam menilai pemahaman pelajar serta kesediaan pelajar (Rashid, 2011). Oleh itu, kajian berkaitan pencapaian akademik penting untuk dikaji supaya dapat memberi gambaran tahap pencapaian akademik pelajar pada masa kini.

\section{Pembelajaran Regulasi Kendiri}

Pembelajaran regulasi kendiri secara umumnya merujuk kepada kemahiran pelajar dalam menentukan keutamaan, mendisiplinkan diri serta kemahiran dalam menguruskan ilmu pengetahuan (Pintrich, 2000). Konsep ini juga merangkumi kebolehan pelajar dalam penguasaan dan pengurusan kendiri di dalam proses pembelajaran (Pintrich, 1997; Zimmerman, 2000; Boekaerts et al., 2000). Pembelajaran regulasi kendiri juga menunjukkan pengaruh dalam meningkatkan pencapaian (Zimmerman dan Schunk, 1989). Kajian lain turut menyatakan regulasi kendiri amat penting bagi mengoptimumkan pembelajaran atas talian dan maju dalam pencapaian akademik (Barnard-Brak et al., 2010; Wang et al., 2013; Zimmerman \& Schunk, 2012).

Definisi regulasi kendiri pelajar menurut Pintrich et al. (1991) adalah penilaian pelajar terhadap 9 aspek iaitu latihan, penjelasan, pengorganisasian, pemikiran kritikal, aturan kendiri metakognitif, pengurusan masa dan persekitaran belajar, meminta bantuan, pembelajaran daripada rakan sebaya dan aturan kendiri usaha. Aspek latihan menurut Pintrich et al. (1991) adalah strategi asas yang melibatkan pembacaan berulang kali untuk membantu mengingati bahan kursus yang penting. Aspek regulasi kendiri yang seterusnya ialah penjelasan di mana strategi ini membantu pelajar untuk menyimpan maklumat yang diperoleh untuk jangka masa yang panjang (Pintrich et al., 1991). Strategi penjelasan merangkumi penafsiran, membuat ringkasan dan analogi bagi membantu pelajar mengintegrasikan maklumat baru dan lama (Pintrich et al., 1991). Aspek ketiga adalah pengorganisasian di mana strategi ini dapat membantu pelajar di dalam kelas atas talian untuk memilih maklumat yang sesuai dan penting (Pintrich et al., 1991). Antara contoh kemahiran pengorganisasian adalah pelajar berkeupayaan untuk membuat pembacaan ringkas dan memilih maklumat penting bagi membuat carta, rajah atau jadual yang mudah difahami. Aspek seterusnya ialah pemikiran kritikal yang merujuk kepada sejauh mana pelajar menggunakan pengetahuan sedia ada untuk digunakan dalam situasi baru dalam menyelesaikan masalah dan membuat keputusan yang betul (Pintrich et al., 1991). Aspek yang kelima adalah aturan kendiri metakognitif merujuk kepada kesedaran, pengetahuan dan kawalan kognisi. Menurut Pintrich et al. (1991) terdapat tiga proses umum yang membentuk aktiviti pengaturan kendiri metakognitif iaitu menjana, memantau dan mengatur aktiviti pembelajaran seperti contoh penetapan matlamat dan analisis tugasan supaya dapat memahami bahan dengan lebih mudah. Bagi aspek pengurusan masa dan persekitaran belajar pula, ia merujuk kepada bagaimana pelajar mengatur masa dan persekitaran mereka (Pintrich et al., 1991). Pengurusan masa melibatkan penjadualan perancangan dan penggunaan masa yang berkesan untuk belajar. Persekitaran belajar pula merujuk kepada keadaan pelajar dalam sesi belajar. Persekitaran perlulah teratur dan tenang serta bebas dari gangguan visual dan audio (Pintrich et al., 1991). Aspek seterusnya ialah peraturan kendiri yang merujuk kepada kemampuan pelajar untuk mengawal usaha mereka dalam menghadapi gangguan dan tugasan yang tidak menarik (Pintrich et al., 1991). Usaha menyelesaikan tugasan mencerminkan komitmen mereka terhadap pembelajaran walaupun terdapat kesukaran (Pintrich et al., 1991). Aspek yang terakhir ialah pembelajaran dengan rakan sebaya (Pintrich et al., 1991). Perbincangan dengan rakan membantu pelajar lebih memahami bahan kursus dari pandangan dan pemahaman yang berbeza (Pintrich et al., 1991). Berkolaborasi dengan rakan sebaya memberi kesan positif terutamanya pada waktu pembelajaran atas talian ini. Kesemua aspek ini akan diukur bagi memberikan gambaran terhadap regulasi kendiri pelajar sepanjang pembelajaran atas talian. 
Kajian berkenaan pembelajaran regulasi kendiri giat dikaji secara meluas di negara luar seperti Indonesia dan Amerika Syarikat (Nani et al., 2019; Richard et al., 2020). Walau bagaimanapun, kajian terkini berkenaan pembelajaran regulasi kendiri terhadap pelajar universiti di Malaysia dalam konteks pembelajaran atas talian masih kurang diterokai sepenuhnya. Kajian terkini kebanyakannya berkenaan pembelajaran regulasi kendiri terhadap pencapaian akademik bagi subjek tertentu dalam konteks pelajar sekolah menengah dan rendah (Ariffin \& Norulhuda, 2019; Haafiz et al., 2018; Annie et al., 2021). Oleh itu, kajian berkenaan pembelajaran regulasi kendiri terhadap pencapaian akademik sepanjang pembelajaran atas talian perlu dikembangkan lagi berikutan topik ini masih belum meluas di Malaysia. Pembelajaran regulasi kendiri memainkan peranan penting dalam meningkatkan pencapaian pelajar. Pencapaian yang baik dapat dilihat apabila pelajar mengambil tindakan autonomi dalam menyiapkan, melaksanakan dan menilai pembelajaran mereka dan ini dapat dilihat sebagai hasil kecenderungan pelajar untuk mengarahkan pembelajaran mereka (Brockett \& Hiemstra, 2018). Oleh itu, penyelidikan berkenaan pembelajaran regulasi kendiri adalah penting untuk dikaji memandangkan ia memberikan impak positif kepada pencapaian akademik pelajar.

\section{Motivasi}

Motivasi adalah keinginan dan rancangan untuk mencapai matlamat (Donsu, 2017). Menurut Aida dan Aziz (2020), motivasi dalam pembelajaran adalah penting kerana ia memberi kesan terhadap pencapaian. Pelajar yang bermotivasi tinggi akan mendorong dirinya dan mempunyai keazaman untuk terus mengikuti pembelajaran tanpa gagal (Aziz \& Aida, 2020). Pernyataan ini disokong oleh Ryan dan Deci (2000) yang menyatakan motivasi pelajar adalah peramal kuat kepada pencapaian akademik mereka. Bersesuaian dengan isu pelajar dalam pembelajaran atas talian, pelajar harus terus berusaha untuk mencapai kejayaan tanpa gagal walaupun menghadapi cabaran mengikuti pembelajaran secara atas talian. Ini adalah kerana motivasi merupakan elemen penting dalam pembangunan dan kecemerlangan dan sekali gus akan memberi input yang maksimum dalam pencapaian akademik. Oleh itu, motivasi yang tinggi diperlukan untuk meneruskan pembelajaran dan aspek ini akan diukur bagi memberikan gambaran terhadap motivasi pelajar dalam mengharungi proses pembelajaran dalam talian sepanjang pandemik Covid-19 (Ricarda et al., 2019).

Terdapat 5 aspek yang diukur bagi memberi gambaran tentang tahap motivasi pelajar sepanjang pembelajaran atas talian iaitu orientasi matlamat intrinsik, orientasi matlamat ekstrinsik, nilai tugasan, kawalan kepercayaan dan efikasi kendiri (Pintrich et al., 1991). Aspek orientasi matlamat intrinsik merujuk kepada sejauh mana pelajar mengambil bahagian dalam tugasan mereka atas sebab minat dan dorongan sendiri tanpa ada paksaan atau mengharap kepada apa-apa ganjaran (Pintrich et al., 1991). Manakala orientasi matlamat ekstrinsik pula merujuk kepada penglibatan pelajar di dalam kelas adalah kerana ganjaran (Pintrich et al., 1991). Motivasi ekstrinsik wujud daripada rangsangan luar dan ia juga boleh dirangsang dalam bentuk pujian, insentif, hadiah dan gred yang baik (Radziah \& M. Hussin, 2013). Aspek ketiga pula iaitu nilai tugasan merujuk kepada persepsi pelajar terhadap bahan kursus. Aspek ini juga memberi gambaran penilaian pelajar sejauh mana bahan kursus yang dipelajari adalah menarik dan penting (Pintrich et al., 1991). Aspek seterusnya iaitu kawalan kepercayaan di mana ia merujuk kepada kepercayaan pelajar tentang usaha mereka untuk belajar akan menghasilkan pencapaian yang baik (Pintrich et al., 1991). Pelajar percaya hasil yang mereka capai adalah bergantung kepada usaha sendiri. Oleh sebab itu, mereka cenderung untuk belajar dengan lebih sistematik (Pintrich et al., 1991). Akhir sekali adalah aspek efikasi kendiri pada pembelajaran dan prestasi yang merujuk kepada penilaian kendiri tentang keupayaan diri untuk menguasai sesuatu tugasan (Pintrich et al., 1991). Manusia lebih cenderung melibatkan diri dalam sesuatu tugasan jika mereka yakin mereka mampu melaksanakannya (Patricia et al., 2021)

Kajian berkenaan motivasi kebanyakannya menyentuh aspek demografi, gaya pembelajaran dan pencapaian akademik (Farah \& Mujaheed, 2021; Zulyna \& Faridah, 2021; Kaviza, 2020). Namun kajian tersebut mengulas isu-isu diluar musim pandemik dan dalam konteks populasi yang berbeza. Oleh itu, penyelidikan berkenaan motivasi adalah penting untuk dikaji memandangkan terdapat perbezaan proses pembelajaran pada musim pandemik. 


\section{Teori Kognitif Sosial}

Teori kognitif sosial oleh Bandura (1986) menyatakan tingkah laku, persekitaran dan kognitif merupakan tiga faktor yang mempunyai hubungan yang signifikan untuk membentuk pembelajaran yang aktif dan teratur serta berinteraksi untuk menggerakkan setiap individu dalam melaksanakan sesuatu. Menurut Bandura (1963) tingkah laku seseorang adalah hasil daripada interaksi antara kognitif dan persekitaran. Dalam teori ini, faktor kognitif menurut Bandura (1994) ialah efikasi diri iaitu keyakinan pada kemampuan sendiri untuk menghadapi dan menyelesaikan masalah dengan efektif. Menurut teori ini juga, tingkah laku yang dimiliki adalah hasil dari pemerhatian (Bandura, 1977). Melalui faktor kognitif, tingkah laku dapat diatur dan dikendalikan. Bandura (1977) percaya pembelajaran dapat dipelajari melalui pemerhatian. Seterusnya, menurut teori ini lagi, persekitaran yang selesa dan kondusif dapat membantu pelajar mencontohi tingkah laku di dalam kelas (Bandura, 1986). Pengkaji memilih teori ini kerana bersesuaian dengan elemen-elemen yang dikaji di dalam konstruk kajian ini iaitu persekitaran pembelajaran yang merujuk kepada tempat belajar yang membolehkan pelajar fokus, teratur, tenang dan bebas dari gangguan visual dan pendengaran supaya pelajar dapat menghubungkan pengetahuan lama dengan yang baharu (Pintrich et al., 1991). Seterusnya ialah faktor kognitif yang melibatkan persepsi, penilaian dan peraturan tingkah laku (Bandura, 1986). Menurut Pintrich (1991), konstruk metakognisi merujuk kepada kawalan kognitif dimana terdapat tiga proses yang membentuk aktiviti kognitif ini iaitu merancang aktiviti seperti penetapan matlamat, memantau aktiviti dan mengatur aktiviti dan ia dianggap dapat meningkatkan prestasi dengan membantu pelajar dalam memeriksa dan membetulkan tingkah laku mereka.

Penyelidikan regulasi kendiri merangkumi banyak bidang fungsi manusia, termasuk kesihatan fizikal dan senaman, disfungsi klinikal dan pekerjaan, seperti pengajaran (O'Leary, 1985; Bandura \& Cervone, 1983; Ashton, 1985). Teori ini juga mendasari kajian Arnie Yuzi dan Ruhizan (2014) yang membuktikan bahawa regulasi kendiri merupakan elemen yang penting dalam menentukan pencapaian akademik pelajar. Justeru, teori kognitif sosial adalah antara teori yang sesuai digunakan dalam mengkaji pembelajaran regulasi kendiri kerana pandemik telah meningkatkan keperluan baharu dimana pelajar melangsungkan pembelajaran secara atas talian dan mereka perlu mengatur tingkah laku mereka untuk meneruskan pembelajaran.

\section{Teori Determinasi Diri}

Teori determinasi diri oleh Deci dan Ryan (2000) adalah teori motivasi dan keperibadian manusia untuk terus konsisten dalam mencapai matlamat. Teori ini mengarahkan motivasi intrinsik dan motivasi ekstrinsik mendorong tingkah laku individu (Deci \& Ryan, 1985). Motivasi intrinsik secara teknikal berkaitan dengan aktiviti yang dilakukan untuk kepentingan, minat dan memberi kepuasan kepada diri sendiri (Deci \& Ryan, 1985). Berbeza dengan motivasi ekstrinsik di mana tingkah laku yang dilakukan untuk alasan selain daripada kepuasan yang wujud, seperti contoh hadiah, penghargaan dan gred (Deci \& Ryan, 1985). Menurut Deci \& Ryan (2000) motivasi intrinsik adalah lebih berpengaruh kepada tingkah laku individu. Dalam konteks kajian ini, konstruk motivasi intrinsik mendorong pelajar supaya dapat menguasai sesi pembelajaran atas alasan minat, rasa ingin tahu dan cabaran untuk mendapat ilmu yang baharu (Pintrich, 1991). Mempunyai motivasi intrinsik, menunjukkan pelajar itu ingin mencapai matlamat untuk dirinya sendiri (Pintrich, 1991). Manakala mempunyai motivasi ekstrinsik pula tidak mendorong pelajar untuk terlibat dengan sesi pembelajaran dengan sendirinya tetapi keterlibatan pelajar adalah kerana untuk mencapai matlamat seperti mendapatkan gred yang baik, penghargaan dan juga untuk membandingkan pencapaian akademik mereka dengan orang lain (Pintrich, 1991).

Beberapa kajian luar telah membuktikan teori ini mempunyai hubungan yang positif dengan pencapaian akademik seperti kajian Taylor et al. (2014) di Kanada dan Sweeden yang telah menunjukkan peranan motivasi intrinsik yang signifikan dalam pencapaian. Selain itu kajian Froiland dan Worrell (2016) menunjukkan bahawa motivasi meramalkan penglibatan pelajar yang seterusnya meramalkan pencapaian yang lebih tinggi. Berdasarkan beberapa kajian yang telah dinyatakan maka terbuktilah terdapat hubungan antara teori determinasi diri dengan pencapaian akademik. Namun kajian lepas tertumpu kepada kajian sebelum berlakunya pembelajaran atas talian. Memandangkan terdapat 
isu kemerosotan pencapaian akademik di kalangan pelajar pada waktu pembelajaran atas talian, SDT adalah antara teori yang sesuai dengan kajian ini kerana motivasi yang tinggi diperlukan untuk meneruskan pembelajaran dan aspek ini akan diukur bagi memberikan gambaran terhadap motivasi pelajar dalam mengharungi proses pembelajaran dalam talian sepanjang pandemik Covid-19.

\section{Metod Kajian}

Kajian ini menggunakan reka bentuk kuantitatif dengan menggunakan pendekatan kajian tinjauan dalam bentuk survei. Kaedah yang yang dipilih dalam kajian ini ialah persampelan rawak mudah. Menurut Kamarul (2015), persampelan rawak mudah digunakan bagi memastikan peluang yang diberikan kepada setiap responden kajian adalah sama. Populasi kajian terdiri daripada 663 pelajar sarjana Fakulti pendidikan, UKM. Berdasarkan kepada jadual penentuan Cohen (2001), seramai 240 pelajar sarjana.

Data dikumpulkan menggunakan soal selidik secara atas talian. Hal ini adalah kerana kekangan untuk berjumpa dengan responden akibat pandemik Covid-19. Soal selidik yang digunakan telah diadaptasi dari Motivated Strategies for Learning Questionnaire (MSLQ) yang telah dibina oleh (Pintrich et al. 1991). Tumpuan soal selidik ini adalah pada tahap motivasi dan pembelajaran regulasi kendiri. Soal selidik terbahagi kepada tiga bahagian iaitu bahagian A, B dan C. Bahagian A adalah berkaitan maklumat demografi responden. Bahagian B pula berkaitan motivasi pelajar yang mengandungi 26 soalan dan $\mathrm{C}$ berkaitan dengan pembelajaran regulasi kendiri yang mempunyai 50 soalan. Kombinasi antara subskala strategi metakognitif dan subskala pengurusan pembelajaran akan menghasilkan skala regulasi kendiri (Pintrich \& De Groot, 1990). Kesemua item di Bahagian B dan Bahagian C soal selidik adalah berbentuk skala likert tujuh mata dari 1 (sama sekali tidak benar) hingga 7 (sangat benar bagi saya). Skor untuk setiap subskala dikira dengan mengambil nilai min item dalam subskala tersebut.

Data dianalisis menggunakan perisian SPSS versi 23.0 secara deskriptif dan inferensi. Data yang dianalisis secara deskriptif melihat kepada nilai peratusan, min strategi belajar dan sisihan piawai bagi setiap konstruk. Jadual 1 di bawah menunjukkan interpretasi skor min yang akan pengkaji gunakan dalam kajian ini.

Jadual 1: Kategori min skala likert 7 tahap

\begin{tabular}{cc}
\hline Skor min & Tahap \\
\hline $5.01-7.00$ & Tinggi \\
$3.01-5.00$ & Sederhana \\
$1.00-3.00$ & Rendah \\
\hline
\end{tabular}

Sumber: Nik Mohd Rahimi (2004)

Seterusnya, analisis secara inferensi melalui ujian Korelasi Pearson pula akan digunakan untuk melihat hubungan antara pembelajaran regulasi kendiri dan motivasi terhadap pencapaian akademik. Jadual 2 di bawah menunjukkan interpretasi nilai pekali korelasi yang akan digunakan dalam kajian ini.

Jadual 2: Interpretasi Pekali Korelasi

\begin{tabular}{cc}
\hline Pekali korelasi (r) & Kekuatan hubungan \\
\hline 0.00 & Tiada Korelasi \\
Kurang 0.19 & Sangat Rendah \\
$0.20-0.39$ & Rendah \\
$0.40-0.69$ & Sederhana \\
$0.70-0.89$ & Tinggi \\
$0.90-1.00$ & Sangat Tinggi \\
\hline
\end{tabular}

Sumber: Cohen \& Holliday (1982) 


\section{Hasil Kajian}

\section{Demografi Responden}

Analisis ini akan membentangkan profil responden kajian ini. Jumlah responden adalah 240 orang pelajar sarjana Fakulti Pendidikan, UKM yang menjalani pembelajaran atas talian. Taburan demografi responden dipaparkan dalam Jadual 3 di bawah.

Jadual 3: Taburan Demografi Responden

\begin{tabular}{llcc}
\hline Demografi & & Bil. & Peratus (\%) \\
\hline \multirow{2}{*}{ Jantina } & Lelaki & 47 & 19.6 \\
& Perempuan & 193 & 80.4 \\
& & & \\
& 25 tahun ke bawah & 38 & 15.8 \\
Umur & $26-35$ tahun & 142 & 59.2 \\
& $36-45$ tahun & 52 & 21.7 \\
& 46 tahun ke atas & 8 & 3.3 \\
& & & \\
Bangsa & Melayu & 202 & 84.2 \\
& Cina & 6 & 2.5 \\
& India & 17 & 7.1 \\
Pencapaian akademik & Lain-lain & 15 & 6.3 \\
& & & \\
& $2.00-2.99$ & 1 & 0.4 \\
& $3.00-3.49$ & 74 & 30.8 \\
& $3.50-4.00$ & 165 & 68.8 \\
\hline
\end{tabular}

\section{Tahap Pembelajaran Regulasi Kendiri}

Analisis seterusnya akan melihat kepada tahap pembelajaran regulasi kendiri pelajar. Jadual 4 menunjukkan skor min secara keseluruhan bagi tahap pembelajaran regulasi kendiri pelajar.

Jadual 4: Min Dan Sisihan Piawai Tahap Pembelajaran Regulasi Kendiri Pelajar

\begin{tabular}{lllc}
\hline & Min & S.P. & Tahap \\
\hline Latihan & 5.49 & .988 & Tinggi \\
Penjelasan & 5.75 & .844 & Tinggi \\
Pengorganisasian & 5.71 & .828 & Tinggi \\
Pemikiran kritikal & 5.66 & .845 & Tinggi \\
Aturan kendiri metakognitif & 5.24 & .683 & Tinggi \\
Masa \& persekitaran pembelajaran & 4.90 & .764 & Sederhana \\
Aturan kendiri usaha & 4.80 & .907 & Sederhana \\
Meminta bantuan & 5.16 & .743 & Tinggi \\
Pembelajaran daripada rakan sebaya & 5.57 & .938 & Tinggi \\
\hline Keseluruhan (Regulasi kendiri) & $\mathbf{5 . 3 6}$ & $\mathbf{. 6 3 9}$ & Tinggi \\
\hline
\end{tabular}

Dalam kajian ini, pembelajaran regulasi kendiri pelajar semasa pembelajaran di atas talian diukur oleh 9 aspek iaitu latihan, penjelasan, pengorganisasian, pemikiran kritikal, aturan kendiri metakognitif, pengurusan masa dan persekitaran belajar, meminta bantuan, pembelajaran daripada rakan sebaya dan aturan kendiri usaha. Dapatan kajian yang dipaparkan dalam Jadual 4 di atas menunjukkan bahawa skor dimensi pengurusan masa dan persekitaran belajar $(\min =4.90, \mathrm{SP}=0.764)$ dan aturan kendiri usaha $(\min =4.80, \mathrm{SP}=0.907)$ adalah berada pada tahap yang sederhana. Manakala skor dimensi yang tinggi pula adalah latihan $(\mathrm{min}=5.49, \mathrm{SP}=0.988)$, penjelasan $(\min =5.75, \mathrm{SP}=0.844)$, pengorganisasian $(\min =5.71, \mathrm{SP}=0.828)$, pemikiran kritikal $(\min =5.66, \mathrm{SP}=0.845)$, aturan kendiri 
metakognitif $(\min =5.24, \mathrm{SP}=0.683)$, meminta bantuan $(\min =5.16, \mathrm{SP}=0.743)$ dan pembelajaran daripada rakan sebaya $(\min =5.57, \mathrm{SP}=0.938)$. Secara keseluruhannya menunjukkan skor tahap pembelajaran regulasi kendiri pelajar semasa pembelajaran di atas talian $(\min =5.36, \mathrm{SP}=0.639)$ adalah di tahap yang tinggi.

\section{Tahap Motivasi}

Analisis seterusnya akan melihat kepada tahap motivasi pelajar. Jadual 5 menunjukkan gambaran jelas analisis deskriptif.

Jadual 5: Min dan Sisihan Piawai Motivasi Pelajar

\begin{tabular}{llll} 
& Min & S.P. & Tahap \\
\hline Orientasi matlamat intrinsik & 5.79 & .779 & Tinggi \\
Orientasi matlamat ekstrinsik & 5.94 & .839 & Tinggi \\
Nilai tugasan & 6.04 & .703 & Tinggi \\
Kawalan kepercayaan & 5.62 & .789 & Tinggi \\
Efikasi kendiri pembelajaran \& prestasi & 5.81 & .727 & Tinggi \\
\hline Keseluruhan (Motivasi pelajar) & $\mathbf{5 . 8 4}$ & $\mathbf{. 6 4 5}$ & Tinggi \\
\hline
\end{tabular}

Tahap motivasi pelajar sarjana semasa pembelajaran atas talian diukur oleh 5 dimensi iaitu orientasi matlamat intrinsik, orientasi matlamat ekstrinsik, nilai tugasan, kawalan kepercayaan dan efikasi kendiri untuk pembelajaran dan prestasi. Hasil kajian seperti yang dipaparkan dalam Jadual 5 di atas menunjukkan bahawa kesemua skor dimensi motivasi pelajar iaitu orientasi matlamat intrinsik ( $\mathrm{min}=$ $5.79, \mathrm{SP}=0.779)$, orientasi matlamat ekstrinsik $(\min =5.94, \mathrm{SP}=0.839)$, nilai tugasan, $(\mathrm{min}=6.04$, $\mathrm{SP}=0.703)$, kawalan kepercayaan $(\mathrm{min}=5.62, \mathrm{SP}=5.62, \mathrm{SP}=0.789)$ dan efikasi kendiri untuk pembelajaran dan prestasi $(\mathrm{min}=0.581, \mathrm{SP}=0.727)$. Secara keseluruhannya menunjukkan skor tahap motivasi pelajar sarjana semasa pembelajaran $(\min =5.84, \mathrm{SP}=0.645)$ berada pada tahap tinggi.

\section{Tahap Pencapaian Akademik}

Analisis seterusnya akan melihat kepada tahap pencapaian akademik pelakar. Jadual 6 menunjukkan kekerapan tahap pencapaian akademik responden.

Jadual 6: Pencapaian Akademik Responden

\begin{tabular}{cccc}
\hline Skor & Tahap & Kekerapan & Peratus \\
\hline $2.00-2.99$ & Sederhana & 1 & 0.4 \\
$3.00-3.49$ & Baik & 74 & 30.8 \\
$3.50-4.00$ & Cemerlang & 165 & 68.8 \\
Jumlah & & 240 & 100.0 \\
\hline
\end{tabular}

Dalam kajian ini, pencapaian akademik merujuk kepada keputusan yang diperoleh oleh pelajar dalam peperiksaan yang diambil mereka. Kajian ini akan menggunakan Purata Nilai Gred Kumulatif (PNGK) kerana ia dapat memberikan maklumat prestasi akademik pelajar sepanjang masa. Tahap pencapaian akademik menunjukkan seramai 1 orang $(0.4 \%)$ memperoleh PNGK $2.00-2.99,74$ orang (30.8\%) memperoleh PNGK 3.00 - 3.50 dan 165 orang (68.8\%) lagi memperoleh PNGK 3.50 - 4.00. Ini menunjukkan bahawa kebanyakan responden yang terlibat dalam kajian ini memperoleh PNGK 3.50 4.00 .

\section{Hubungan Antara Pembelajaran Regulasi Kendiri, Motivasi dan Pencapaian Akademik}

Hasil kajian ini adalah untuk menjawab objektif dan persoalan kajian iaitu mengenal pasti hubungan antara pembelajaran regulasi kendiri dan motivasi terhadap pencapaian akademik pelajar sarjana sepanjang pembelajaran atas talian. 


\section{Ho1: Tidak terdapat hubungan yang signifikan antara pembelajaran regulasi kendiri dengan pencapaian akademik.}

Hasil kajian seperti yang dipaparkan dalam Jadual 7 menunjukkan dimensi pembelajaran regulasi kendiri dari aspek latihan $(\mathrm{r}=0.361, \mathrm{p}<0.01)$; penjelasan $(\mathrm{r}=0.452, \mathrm{p}<0.01)$; pengorganisasian $(\mathrm{r}=$ $0.388, \mathrm{p}<0.01)$; pemikiran kritikal $(\mathrm{r}=0.387, \mathrm{p}<0.01)$; aturan kendiri metakognitif $(\mathrm{r}=0.354, \mathrm{p}<$ $0.01)$; masa dan persekitaran pembelajaran $(\mathrm{r}=0.299, \mathrm{p}<0.01)$; aturan kendiri usaha $(\mathrm{r}=0.267, \mathrm{p}<$ $0.01)$; meminta bantuan $(\mathrm{r}=0.268$, $\mathrm{p}<0.01)$; dan pembelajaran daripada rakan sebaya $(\mathrm{r}=0.384, \mathrm{p}<$ $0.01)$ mempunyai hubungan yang signifikan yang rendah hingga sederhana dengan pencapaian akademik pelajar sarjana sepanjang pembelajaran atas talian. Secara keseluruhan, dapatan menunjukkan pembelajaran regulasi kendiri $(r=0.462, \mathrm{p}<0.01)$ mempunyai hubungan yang signifikan yang sederhana dengan pencapaian akademik pelajar sarjana sepanjang pembelajaran atas talian. Dengan itu, Ho1 adalah ditolak.

Jadual 7: Hubungan Antara Regulasi Kendiri Pelajar Dengan Pencapaian Akademik

\begin{tabular}{|c|c|c|}
\hline & Penca & emik \\
\hline & $\mathbf{R}$ & Sig. $\mathbf{P}$ \\
\hline Latihan & $0.361^{* * *}$ & .000 \\
\hline Penjelasan & $0.452^{* *}$ & .000 \\
\hline Pengorganisasian & $0.388^{* *}$ & .000 \\
\hline Pemikiran kritikal & $0.387^{* *}$ & .000 \\
\hline Aturan kendiri metakognitif & $0.354^{* *}$ & .000 \\
\hline Masa \& persekitaran pembelajaran & $0.299^{* *}$ & .000 \\
\hline Aturan kendiri usaha & $0.267^{* *}$ & .000 \\
\hline Meminta bantuan & $0.268^{* *}$ & .000 \\
\hline Pembelajaran daripada rakan sebaya & $0.384^{* *}$ & .000 \\
\hline Keseluruhan (Regulasi kendiri) & $0.462^{* * *}$ & .000 \\
\hline
\end{tabular}

\section{Ho2: Tidak terdapat hubungan yang signifikan antara motivasi pelajar dengan tahap pencapaian akademik.}

Jadual 8 menunjukkan hasil kajian dimana dimensi motivasi pelajar dari aspek orientasi matlamat intrinsik $(\mathrm{r}=0.351, \mathrm{p}<0.01)$; orientasi matlamat ekstrinsik $(\mathrm{r}=0.318, \mathrm{p}<0.01)$; nilai tugasan $(\mathrm{r}=$ $0.413, \mathrm{p}<0.01)$; kawalan kepercayaan $(\mathrm{r}=0.251, \mathrm{p}<0.01)$; dan efikasi kendiri pembelajaran \& prestasi $(\mathrm{r}=0.380, \mathrm{p}<0.01)$ mempunyai hubungan yang signifikan yang rendah hingga sederhana dengan pencapaian akademik pelajar sarjana sepanjang pembelajaran atas talian. Secara keseluruhan, dapatan menunjukkan motivasi pelajar $(\mathrm{r}=0.405, \mathrm{p}<0.01)$ mempunyai hubungan signifikan yang sederhana dengan pencapaian akademik pelajar sarjana sepanjang pembelajaran atas talian. Dengan itu, Ho2 adalah ditolak.

Jadual 8: Hubungan Antara Motivasi Pelajar Dengan Pencapaian Akademik

\begin{tabular}{lcc}
\hline & \multicolumn{2}{c}{ Pencapaian akademik } \\
\cline { 2 - 3 } & $\mathbf{R}$ & Sig. $\mathbf{P}$ \\
\hline Orientasi matlamat intrinsik & $0.351^{* *}$ & .000 \\
Orientasi matlamat ekstrinsik & $0.318^{* *}$ & .000 \\
Nilai tugasan & $0.413^{\text {*** }}$ & .000 \\
Kawalan kepercayaan & $0.251^{* *}$ & .000 \\
Efikasi kendiri pembelajaran \& prestasi & $0.380^{* *}$ & .000 \\
\hline Keseluruhan (Motivasi pelajar) & $\mathbf{0 . 4 0 5}^{\text {*** }}$ & $\mathbf{. 0 0 0}$ \\
\hline
\end{tabular}

$* * \mathrm{p}<0.01$ 
Dapatan kajian menunjukkan terdapat hubungan signifikan yang sederhana antara pembelajaran regulasi kendiri dan motivasi pelajar sarjana semasa pembelajaran di atas talian. Sebanyak 2 hipotesis telah diuji dalam kajian ini. Oleh itu, dapat dirumuskan kedua-dua hipotesis dalam kajian ini ditolak.

\section{Jadual 9: Rumusan Hipotesis}

\begin{tabular}{llc}
\hline & \multicolumn{1}{c}{ Hipotesis } & Keputusan \\
\hline Ho1: & $\begin{array}{l}\text { Tidak terdapat hubungan yang signifikan antara pembelajaran } \\
\text { regulasi kendiri dengan tahap pencapaian akademik }\end{array}$ & Ditolak \\
Ho2: & $\begin{array}{l}\text { Tidak terdapat hubungan yang signifikan antara motivasi pelajar } \\
\text { dengan tahap pencapaian akademik. }\end{array}$ & Ditolak \\
\hline
\end{tabular}

\section{Perbincangan Kajian}

Kajian ini bertujuan mengenal pasti hubungan antara pembelajaran regulasi kendiri dan motivasi pelajar sarjana semasa pembelajaran atas talian terhadap pencapaian akademik pelajar. Hasil dapatan kajian mendapati terdapat hubungan signifikan yang sederhana antara pembelajaran regulasi kendiri dengan pencapaian akademik pelajar sarjana. Dalam erti kata lain pembelajaran regulasi kendiri pelajar dilihat mampu meningkatkan pencapaian akademik pelajar walaupun pembelajaran berlaku di atas talian. Dapatan ini selari dengan kajian-kajian lepas yang menunjukkan bahawa terdapat hubungan positif antara regulasi kendiri dengan pencapaian akademik (Haafiz, 2018; Adel El Adl \& Hussain, 2020). Dengan regulasi kendiri, pelajar mewujudkan tabiat belajar yang lebih baik dan oleh itu kemahiran belajar mereka diperkukuhkan (Adel El Adl \& Hussain, 2020). Hal ini bermakna dalam usaha untuk mendapatkan pencapaian akademik yang baik, peranan yang dimainkan oleh pembelajaran regulasi kendiri tidak boleh diabaikan. Ini telah membuktikan bahawa pencapaian akademik melalui amalan regulasi kendiri mampu mempengaruhi dan meningkatkan pencapaian akademik. Oleh itu wajar untuk pelajar mempraktikkan semua item dalam pembelajaran regulasi kendiri sekiranya mereka ingin mendapatkan pencapaian akademik yang baik. Hal ini kerana semakin tinggi pembelajaran regulasi kendiri pelajar, semakin tinggi pencapaian akademik pelajar. Dapatan ini bertepatan dengan teori kognitif sosial oleh Bandura (1986), di mana pembelajaran regulasi kendiri adalah proses pembelajaran sendiri dengan mengambil peduli tentang faktor persekitaran, tingkah laku dan usaha kendiri.

Seterusnya, dapatan kajian juga menunjukkan bahawa terdapat hubungan signifikan antara motivasi dengan pencapaian akademik namun hubungan yang diperoleh adalah sederhana. Dalam erti kata lain motivasi dilihat mampu mempengaruhi pencapaian akademik pelajar. Ini selari dengan kajian Zulyna dan Faridah (2021) yang menunjukkan hubungan signifikan antara motivasi dengan pencapaian akademik pelajar. Penjelasan ini turut disokong oleh Rima et al. (2020) yang telah menjalankan kajian berkenaan komponen motivasi dan mendapati nilai tugasan antara penyumbang tertinggi kepada pencapaian akademik. Dapatan kajian ini juga telah menyatakan nilai tugasan adalah antara penyumbang tertinggi. Ini membuktikan pelajar sarjana, UKM merasakan tugasan di dalam kursus amat penting, menarik dan berguna pada mereka. Perkara ini turut dijelaskan oleh Azhar (2017) bahawa faktor dalaman seperti minat mempengaruhi pencapaian akademik. Dapatan ini juga beretepatan dengan teori determinasi kendiri yang di perkenalkan oleh Deci dan Ryan (1985). Teori ini memperlihatkan bahawa individu termotivasi untuk berubah oleh motivasi intrinsik adalah lebih tinggi dari motivasi ekstrinsik. Secara keseluruhan, dapat disimpulkan bahawa pelajar yang mempunyai tahap motivasi yang tinggi dapat memberi kesan yang baik kepada pencapaian akademik mereka dan berjaya mengadaptasi diri dengan perubahan pembelajaran secara atas talian. Secara keseluruhan, dapatan kajian ini memberikan impak dan gambaran bahawa aspek pembelajaran regulasi kendiri, motivasi dan pencapaian akademik pelajar berada pada tahap yang baik. Selain itu juga, kajian ini mengukuhkan lagi kesesuaian pendekatan teori kognitif sosial dan determinasi diri dalam konteks masyarakat Malaysia. 


\section{Kesimpulan}

Kesimpulannya, kajian ini membuktikan pembelajaran regulasi kendiri dan motivasi mempunyai hubungan yang signifikan dengan pencapaian akademik pelajar. Oleh itu pengkaji mencadangkan agar pelajar dapat mengekalkan tahap motivasi di samping menguasai kemahiran pembelajaran regulasi kendiri bagi mengekalkan pencapaian akademik di tahap yang tinggi. Keseluruhannya, kajian ini dilihat dapat menyumbang dalam pemantapan motivasi dan pembelajaran regulasi kendiri pelajar IPT dalam norma baharu. Dapat dirumuskan bahawa pelajar sarjana Fakulti Pendidikan, UKM dilihat mampu beradaptasi dengan norma baharu dengan memperoleh pencapaian akademik yang baik.

Namun begitu, kajian ini mempunyai beberapa limitasi dan memerlukan penambahbaikan pada kajian akan datang. Dapatan kajian ini tidak dapat digeneralisasikan kepada keseluruhan pelajar di Malaysia. Hal ini adalah kerana kajian ini hanya melibatkan sampel dari satu fakulti di sebuah IPT sahaja. Oleh itu, kajian akan datang dicadangkan dilakukan pada sampel yang lebih besar di beberapa IPT. Selain itu, di cadangkan agar kajian yang akan datang menggunakan soal selidik yang pelbagai. Tambahan lain kajian boleh dilakukan menggunakan kaedah pemerhatian dan temu bual responden untuk mendapatkan dapatan yang lebih tepat.

Walaupun terdapat beberapa limitasi, dapatan kajian ini diharapkan dapat memberi panduan kepada penyelidikan yang akan datang. Implikasi daripada kajian ini adalah kepada pihak universiti dan pensyarah di mana terdapat keperluan membangun dan mengintegrasikan modul motivasi dan pembelajaran regulasi kendiri dalam setiap sesi pembelajaran bagi mengekalkan dan memantapkan pencapaian akademik pelajar.

\section{Rujukan}

Ahmid, M. H., \& Abdullah, M. K. (2020). Self-regulated learning among non-Arab students: Contribution of students' motivational beliefs in learning Arabic language. Quantum Journal of Social Sciences and Humanities, 1(2), 28-37.

Azhar Md Sabil, Shamsudin Othman, Abdul Rasid Jamian \& Rozita Radiah Said. (2020). Keberkesanan penggunaan Frog VLE terhadap pengajaran dan pembelajaran komponen sastera dalam mata pelajaran Bahasa Melayu murid sekolah menengah. Jurnal Kurikulum \& Pengajaran Asia Pasifik, 8(4), 50-55.

Azman Ab Rahman, Nurul Nadia Nozlan, Hussein 'Azeemi Abdullah Thaidi, Muhammad Firdaus Ab Rahman \& Mohamad Anwar Zakaria. (2020). Kaedah pengajaran dalam talian guru bahasa melayu dan motivasi murid sekolah jenis kebangsaan cina sepanjang tempoh perintah kawalan pergerakan. Jurnal Pendidikan Bahasa Melayu - JPBM, 11(1), 57-74.

Bandura, A., \& Cervone, D. (1983). Self-evaluative and self- efficacy mechanisms governing the motivational effects of goal systems. Journal of Personality and Social Psychology, 45, 10171028.

Bandura, A., Grusec, J. E., \& Menlove, F. L. (1967). Some social determinants of self-monitoring reinforcement systems. Journal of Personality and Social Psychology, 5, 449- 455.

Barnard-Brak, L., Paton, V. O., \& Lan, W. Y. (2010). Profiles in self-regulated learning in the online learning environment. International Review of Research in Open and Distributed Learning, $11(1), 61-80$.

Barry J. Zimmerman. (2008). Role of social-cognitive and self-regulatory processes in students' learning and motivation. American Educational Research Journal, 45(1), 166-183.

Bolatov, A.K., Seisembekov, T.Z., Askarova, A.Z. (2021). Online-Learning due to COVID-19 improved mental health among medical students. Med.Sci.Educ., 31, 183-192.

Carter Jr, R.A., Rice, M., Yang, S. and Jackson, H.A. (2020), "Self-regulated learning in online learning environments: strategies for remote learning", Information and Learning Sciences, 121 (5), 321-329.

Chua, Y.P. (2014). Buku 1: Kaedah Penyelidikan. McGraw-Hill Education Ed ke-2. Kuala Lumpur: McGraw-Hill Education. 
Creswell, J.W. 2012. Educational Research: Planning, Conducting and Evaluating Quantitative and Qualitative Research. Pearson 4th ed. Boston, MA: Pearson Education, Inc.

Dan Wang \& Mas Nida Md Khambari. (2020). The application of game-based learning model in English sentence learning. The Malaysian Journal Online of Educational Technology, 8(1), $63-$ 71.

Deci, E. L., \& Ryan, R. M. (2020). Self-determination theory and the facilitation of intrinsic motivation, social development, and well-being. American Psychologist Journal, 55, 68-78.

El-Adl, A. \& Alkharusi, H. (2020). Relationships between self-regulated learning strategies, learning motivation and mathematics achievement. Cypriot Journal of Educational Science, 15(1), 104111.

Eom, Y., \& Reiser, R. A. (2000). The effects of self-regulation and instructional control on performance and motivation in computer-based instruction. International Journal of Instructional Media, 27(3), 247-261.

Farah Wazeera \& Mujaheed Hassan. (2021). Konsep kendiri dan gaya pembelajaran terhadapmotivasi akademik dalam kalangan mahasiswa. Malaysian Journal of Social Sciences dan Humanities, 6(2),75-105.

Felisitas A Sri, Monika Luhung \& Devanus Lahardo. (2020). Analisis faktor pengaruh studi from home (sfh) karena wabah covid-19 terhadap prestasi akademik mahasiswa Stikes Panti Waluya Malang. Jurnal Keperawatan Malang, 5(2), 114- 126.

Frances A. Rowe \& Jennifer A. Rafferty. (2013). Instructional design interventions for supporting selfregulated learning: enhancing academic outcomes in postsecondary e-learning environments. Journal of Online Learning and Teaching, 9(4), 590-60.

Froiland, J. M., \& Worrell, F. C. (2016). Intrinsic motivation, learning goals, engagement, and achievement in a diverse high school. Psychology in the Schools, 53(3), 321-336.

Gable, R. K., \& Wolfe, M. B. (1993). Instrument development in the affective domain: Measuring attitudes and values in corporate and school settings. Boston: Kluwer Academic Publishers.

Hardré, P. L., \& Reeve, J. (2003). A motivational model of rural students' intentions to persist in, versus drop out of high school. Journal of Educational Psychology, 95(2), 347-356.

Hashiroh Hussain \& Norshuhada Shiratuddin. (2016). Kebolehpercayaan dan korelasi elemen multimedia dan antara muka tablet dalam menilai penceritaan digital. Asia Pacific Journal of Educators and Education, 31, 27-45.

Hee Jee Mei \& Siti Liyana Binti Mohamad Yusuff. (2014). Hubungan antara tahap motivasi dengan pencapaian akademik pelajar pendidikan jarak jauh Universiti Sains Malaysia. Journal of Science \& Mathematics Education, 1, 1-11.

Judith, $\quad$ B. (2005). Doing Your Research Project, 4th Edition. Open University Press.

Kanammah Manukaram, Melissa Ng Lee Yen Abdullah dan Shahizan Hasan. (2014). Pengaruh faktor psikologi terhadap pembelajaran regulasi kendiri murid sekolah rendah Asia Pacific Journal of Educators and Education, 29(11), 39-54.

Kariya Halimatus Saadiah. (2020). Faktor-faktor yang mempengaruhi pencapaian akademik pelajar Politeknik METrO Betong Sarawak. Jurnal Dunia Pendidikan, 2(4), 9-18.

Katz, I., Eilot, K., \& Nevo, N. (2014). "I'll do it later": Type of motivation, self-efficacy and homework procrastination. Motivation and Emotion, 38(1), 111-119.

Kaur, K., \& Arora, R. (2018). Mathematic anxiety of secondry school students in relation of selfmotivation, self-regulation and responsibility of emotions, self-esteem besides confidence with metacognition. Journal of Humanities and Social Sciences, 9(4), 965-974.

Kaviza, M. (2020). Kesan penggunaan sumber-sumber sejarah berdasarkan model motivasi arcs terhadap peningkatan motivasi dalam kalangan murid tingkatan empat. Malaysian Journal of Social Sciences and Humanities (MJSSH), 5(7), 136 - 145.

Krejcie, R. V \& Morgan, D.W. (1970). Determining sample size for research activities. Educational and Psychological Measurement, 30(3), 607-610.

Lim, C. L., Ab Jalil, H., Maa'rof, A. M., \& Saad, W. Z. (2020). Self-regulated learning as a mediator in the relationship between peer learning and online learning satisfaction: A study of a private university in Malaysia. Malaysian Journal of Learning \& Instruction, 17(1), 51-75.

Makhtar, N. N., Rosli, S. N. A., \& Taha, H. (2021). Kesan jenis pembelajaran dalam talian terhadap sikap, motivasi dan pencapaian pelajar bagi subjek Fizik. Journal of Science and Mathematics Letters, 9(1), 60-76. 
Mohd Arshad, Arni Yuzie \& Yasin Ruhizan. (2014). Strategi pembelajaran regulasi kendiri dalam meningkatkan pencapaian subjek sains: Kajian meta analisis. The 4th International Conference on Learner Diversity, hlm 17-25.

Mohammad Haafiz Amid \& Khalid Johari. (2016). Kertas Konsep: Hubungan antara Kepercayaan Motivasi dan Pembelajaran Regulasi Kendiri dengan Pencapaian Bahasa Arab di Kalangan Pelajar Sekolah Menengah di Sabah. Proceeding International Conference on Education and Psychology, hlm 323-333.

Mohammad Haafiz Ahmid, Mohd Khairuddin Abdullah, Khalid Johari, Arbiah Maddahiri, Hairi Asul, Mahamod, Z., Mazlan, R., Amin, N., \& Abd. Rahman, M. Z. (2021). Tahap penguasaan kemahiran membaca dan menulis murid. Murid B40 dalam Pembelajaran Bahasa Melayu. Journal of Malay Language, Education and Literature, 12(1), 40-62.

Mohd Hazli, Maimun Lubis \& Mohd Alias. (2019). Motivasi intrinsik dan ekstrinsik pelajar dalam aktiviti kemahiran membaca teks Arab. Global Journal Al-Thaqafah, 8, 97-107.

Muhammad Ikmal Rezal Othman, Nurazwa Ahmad \& Nor Kamariah Kamaruddin. (2018). Hubungan antara motivasi intrinsik dan ekstrinsik dengan pencapaian akademik pelajar UTHM. Malaysian Journal of Social Sciences and Humanities (MJSSH), 3(2), 57-64.

Nayak, M.S.D.P. \& Narayan, K.A. (2019). Strengths and Weakness of Online Surveys. IOSR Journal of Humanities and Social Science, 24(5), 31-38.

Nurul Hafizhoh, Norfiza Apfandi, Nurul Suzaina Joli \& Rorlinda, Yusof. (2020). Track dalam PdP Sejarah: Tinjauan terhadap motivasi pelajar. International Journal of Education and Pedagogy, 2(1), 83-97.

Nur Syarafina Binti Abdul Rahman, Zainal Fitri \& Ying Leh Ling. (2020). Kepentingan kemudahan teknologi dan motivasi membentuk kesedaran pelajar dalam pembelajaran digital. National Research Innovation Conference, hlm 1-13.

Oducado, Ryan Michael and Estoque, Homelo. (2021). Online learning in nursing education during the COVID-19 pandemic: Stress, satisfaction, and academic performance (2021). Journal of Nursing Practice, 4(2):143-153.

Pintrich, P. R. (2003). A motivational science perspective on the role of student motivation in learning and teaching contexts. Journal of Educational Psychology, 95, 667-686.

Pintrich, P. R., De Groot, E. V. (1990). Motivational and self-regulated learning component of classroom academic performance. Journal of Educational Psychology, 82, 33-40.

Pintrich, P. R., Smith, D. A. F., Garcia, T., \& McKeachie, W. J. (1993). Reliability and predictive validity of the Motivated Strategies for Learning Questionnaire (MSLQ). Educational and Psychological Measurement, 53, 801-813.

Raskova Octaberlina \& Afif Ikhwanul Muslimin. (2020). Education EFL student's perspective towards online learning barriers and alternatives using moodle/google classroom during covid-19 pandemic. International Journal of Higher, 9(6), 1-9,

Rima Faradila, Amelia Pramono \& Marindra Firmansyah. (2020). Hubungan Motivasi dan Strategi Belajar terhadap Indeks Prestasi Semester Mahasiswa Kedokteran. Jurnal Bio Komplementer Medicine, 7(1), 1-7.

Rowe F. A \& Rafferty J. (2013). Theories and models about self-regulated learning are important to educators attempting to understand why some learners succeed and others have difficulty in academic settings. Journal of Online Learning and Teaching, 9(4), 590-601.

Royo M.A, Mahmood H. (2011). Faktor-faktor kelemahan yang mempengaruhi pencapaian cemerlang pelajar dalam mata pelajaran Reka Cipta. Journal of Educational Psychology and Counseling, 2(6), 145-174.

Ryan, R. M., \& Deci, E. L. (2000). Intrinsic and extrinsic motivations: Classic definitions and new directions. Contemporary Educational Psychology, 25, 54-67.

Ryan, R. M., \& Deci, E. L. (2017). Self-determination theory: Basic psychological needs in motivation, development, and wellness. New York, NY: Guilford Publishing.

Ryan, R. M., Vansteenkiste, M., \& Soenens, B. (2019). Reflections on self-determination theory as an organizing framework for personality psychology: Interfaces, integrations, issues, and unfinished business. Journal of Personality, 87(1), 115-145.

Santrock, J. W. (2006). Materialism Impedes our Psychosocial Growthlife-span development (10th ed.). Boston, USA: McGraw-Hill. 
Suhaniz Fazlin \& Mohd Effendi @ Ewan. (2020). Faktor yang mempengaruhi keterlibatan pelajar dalam pembelajaran matematik: sorotan literatur bersistematik. Jurnal Dunia Pendidikan, 2(3), 173-187.

Susana Rodríguez, José C. Núñez, Antonio Valle, Carlos Freire, María del Mar Ferradás \& Carolina Rodríguez-Llorente. (2019). Relationship between students' prior academic achievement and homework behavioral engagement: the mediating/moderating role of learning motivation. Frontiers in Psychology, 10, 1-10.

Taylor, G., Jungert, T., Mageau, G. A., Schattke, K., Dedic, H., Rosenfield, S., \& Koestner, R. (2014). A self-determination theory approach to predicting school achievement over time: The unique role of intrinsic motivation. Contemporary Educational Psychology, 39, 342-358.

Yasuhiro Kotera \& Su-Hie Ting. (2021). Positive psychology of Malaysian University Students: impacts of engagement, motivation, self-compassion, and well-being on mental health. International Journal of Mental Health and Addiction, 19, 227-239

Zimmerman, B. J. (1990). Self-Regulated Learning and Academic Achievement: An Overview. Educational Psychology, 25(1), 1-3.

Zulyna Adila Zainuddin \& Faridah Mydin Kutty. (2021). Hubungan antara efikasi kendiri dan motivasi terhadap pencapaian akademik pelajar perempuan jurusan STEM. Malaysian Journal of Social Sciences and Humanities (MJSSH), 6(3), 180-190. 